\title{
SALT AND WATER BALANCE IN ANIMAL LIFE
}

$\mathrm{T}$

HE mechanisms by which salt and water balance is maintained in the majority of the groups of colomate animals are now fairly well understood. Such mechanisms are of importance not only in all freshwater animals, which must always protect themselves against the continual loss of salts and the uptake of water, but also in many marine animals, where it is found that the salt and water content of the body is also carefully regulated. There are, however, many aspects of the functioning of these mechanisms about which very little is known at present. For example, salt balance is generally maintained by the activity of a specialized group of cells which are localized, often in the respiratory membranes, and which are capable of doing work to sustain a gradient of salt concentration across the membrane. Although the gross location of these cells can generally be inferred, we still have very little knowledge of their nature and properties at a cytological level. Histological and cytochemical studies under conditions of varying salt concentration can help in their identification and characterization.

The quantitative measurement of salt and water movements in animals is another important aspect which, as yet, has received little attention. It is only by such measurements that it is possible to discover the factors upon which these movements depend and the extent to which they can be regulated and controlled by the animal itself. The general availability of radioactive and other forms of tracer substances has now made this type of measurement much easier.

Both cytological and quantitative investigations of the mechanisms of salt and water balance in animals were considered in a symposium under the above title which was held as a joint session of Sections $D$ and $I$ (Zoology and Physiology and Biochemistry) at the British Association meeting at Glasgow on September 1.

Dr. T. Vickers (University of Cambridge) took up once again the question of the cells responsible for salt secretion in the teleost fish. Nearly thirty years ago Homer Smith showed that in the marine teleosts salt and water balance is achieved by the ingestion of large amounts of sea-water, the intestinal absorption of water and salts from this and the subsequent extrarenal excretion of the excess salt. Keys demonstrated that this salt was secreted by the gills, and Keys and Willmer identified large eosinophil cells in the branchial epithelium of the eel and suggested that these cells were responsible for salt secretion. Vickers showed that a similar type of cell appears in the gill lamellæ of the brackish- and fresh-water guppy, Lebistes reticulatus, when this is adapted to salt solutions. Under these conditions, small, previously undifferentiated cells are mobilized and they develop into large eosinophil cells the size of which depends on the salt load. They appear to be active cells with many mitochondria but give negative tests for mucus when fully developed. During the normal development of these cells they have small pits at their distal ends which are mucus-positive but which disappear as the cell enlarges. It is interesting that if the animal fails to adapt itself to the new salinity these pits enlarge and become filled with mucus, the cell cytoplasm becomes reduced and the cell now strongly resembles a normal goblet cell. It is clear that in this epithelium transformation from one functional cell type to another can take place. The primary stimulus for the formation of the salt-secreting cell is presumably the increase in salt load, but whether this can directly affect the branchial epithelium or whether the response is induced indirectly is not yet known.

That it is possible to induce a transformation of epithelial cells directly was demonstrated by Dr. H. B. Fell (University of Cambridge). She showed that vitamin A controls the differentiation of certain types of epithelia, the respiratory epithelium being especially susceptible. Thus, for example, the epithelium of the trachea is composed typically of columnar, ciliated and mucous cells. In the absence of vitamin A the ciliated and mucous cells disappear and a squamous epithelium is formed. The direct nature of this effect can be demonstrated by the behaviour of embryonic chick skin in tissue culture. A keratinizing epithelium of the squamous type is formed in a normal culture medium, but if vitamin $\mathbf{A}$ is present the keratin process is suppressed and the cells produce a mucous secretion. In some cases ciliated cells may also be produced. If the tissue is returned to the normal medium, after a few days of intensified secretion the basal cells proliferate and the squamous epithelium is regenerated.

Dr. R. Morris (University of Nottingham) showed that cell changes occurred in the respiratory epithelium of the river lamprey, Petromyzon fluviatilis, also. $\mathrm{He}$ described how the adult lampreys, which are found in the sea and in estuaries, come upstream to spawn and during the process lose their marine osmoregulatory mechanism, replacing it by a freshwater one. Animals taken from fresh water vary greatly in their behaviour in 33 per cent sea-water. Mature animals lose much water and their blood concentration rises to that of the outside solution. The fresh-run animals are very variable: some behave like mature animals, whereas others are able to maintain both salt and water balance. In the latter case, the mechanism closely resembles that found in the marine teleost and, in fact, the lampreys only differ in their greater water permeability. Just as in the marine teleost the gill epithelium contains salt-secreting cells, but its nature is variable. In many fresh-run animals the secreting cells are regressing and other cells, which are typical of the freshwater animals, are taking their place. The breakdown of the marine mechanism involves not only the disappearance of the secretory cells but also the loss of swallowing capacity as the animal ceases to feed in fresh water and the gut degenerates and there is an increase in permeability of the body surface.

The lampreys probably developed in fresh water and evolved their marine osmoregulatory mechanism quite independently of the teleosts.

The extent to which a knowledge of the mechanism of salt and water balance in the lower vertebrates, such as the cyclostomes and fishes, can assist in deducing the type of habitat in which the vertebrate 
group as a whole evolved was discussed by Dr. J. D. Robertson (University of Glasgow). A widely held view, due mainly to Homer Smith and Marshall, is that certain features of these mechanisms, especially the presence of the peculiar glomerular kidney, point to a freshwater origin for the vertebrates. Robertson challenged this view. He showed that the palæontological evidence indicates that the earliest vertebrates, the Ostracoderms and the Acanthodians, lived in the coastal waters of the sea, and their remains, found in the rocks of the Ordovician and Silurian periods, are mostly associated with known marine invertebrates. At the same time, geochemical evidence suggests that the seas in Ordovician times were probably almost as saline as they are to-day. Robertson claimed that the inferences which could be drawn from the physiological features of presentday vertebrates are not opposed to this view. He brought forward the fact that all non-vertebrate chordates are marine and their blood composition, where known, is similar to that of sea water. Although the salt content of the blood of almost all the aquatic vertebrates is much less than that of sea water, the blood of the myxinoid cyclostomes-a very primitive vertebrate group-is not dissimilar, and this may be a primary feature. Finally, he suggested that the glomerular kidney is not necessarily a freshwater adaptation. It may well have existed in marine protovertebrates as it does to-day in the marine elasmobranchs and myxinoids. In these marine animals the glomerular filtration surface may be practically as large as that of the freshwater teleosts.

There seems little to be gained by pursuing this question further until new facts have come to light. On the physiological side, many more studies on the quantitative aspects of renal function in the cyclostomes and fishes would do much to increase our knowledge on this fundamental issue.

A quantitative approach to the problems of salt balance was adopted by Dr. J. Shaw (King's College, Newcastle), who described an analysis of sodium uptake by the freshwater crayfish, Astacus pallipes. A steady state is achieved when the normal sodium loss is balanced by an equal uptake of sodium from the environment. 'The rate of sodium uptake can be conveniently measured by the use of a radioactive sodium isotope. The rate of sodium uptake depends on the external sodium concentration and a maximum rate is approached at concentrations as low as $1 \mathrm{~m} . \mathrm{mole} / \mathrm{l}$. Above a certain minimum value balance can be achieved at any external concentration, since the uptake-rate is also regulated by the internal sodium concentration. A fall in the blood sodium concen. tration of 10 per cent or less may increase the rate of uptake by as much as five times. The system is a self-regulating one and results in the maintenance of the blood sodium concentration despite changes in the sodium content of the environment or the presence of other factors which may affect the sodium uptake. rate.
J. SHAW

\section{AQUATIC AND AIR POLLUTION}

\begin{abstract}
A
SYMPOSIUM on "The Effects of Pollution on Living Material", organized by the Institute of Biology, was held at the rooms of the Royal Geographical Society on September 25 and 26 . The general and scientific interest in various aspects of this subject may be gauged from the fact that 380 registrations were received, more than a hundred of which were from industrial organizations, public authorities and similar bodies. The symposium was divided into four sessions, each dealing with one separate aspect of the problem : these were river, estuarine and air pollution, and pollution by radioactive substances.

In the field of air pollution the immediate need is clearly to study its effect on man, but there was evidence at this symposium that other aspects of the problem are not being neglected. Recent studies by Gorham $^{1}$ suggest that air pollution is increasing the concentrations of sulphuric acid in atmospheric precipitation in the Lake District and "will presumably hasten deterioration of already heavily leached Lake District soils". Moorland and high tarn communities may well be affected. Changes of this sort brought about by air pollution, though difficult to study except in local areas and special habitats, may be widespread.

Before about 1945 the biologist studying water pollution was primarily interested in the effects of polluting discharges on river and estuarine communities. The change in community structure often gave a useful measure of the severity of the pollution. The mode of action of the pollutants which resulted in such changes was rarely studied and, with the exception of organic pollution associated with low oxygen concentrations, practically no information
\end{abstract}

was gathered on how these selective forces operated at organismic level. This state of affairs is generally true to-day, although a recent advance has been made concerning the chemical factors important in the distribution and deaths of fish in a sewage effluent channel ${ }^{2}$.

Since the end of the Second World War, however, there has been an increasing interest in the effects of organisms on the polluted environment. In pollution by radioactive wastes, although there is no evidence of changes in community structure, the activity of organisms in accumulating and afterwards roleasing radioisotopes is of the utmost importance in determining permissible discharges. In the field of 'conventional' water pollution similar trends are evident, and it seems likely, from the papers presented, that in the near future it will be possible to make estimates of some of the effects which organisms have on their environment.

The first speaker in the session concerning river pollution, Mr. F. T. K. Pentelow (Ministry of Agriculture, Fisheries and Food), began by admitting the difficulty of defining pollution. It could be said, however, that water is polluted when it becomes unfit for some use to which it could be put in its natural state. Mr. Pentelow directed attention to the many improvements which have occurred in British rivers over the past thirty years at a time of great industrial and urban expansion in spite of a major slump, rearmament, war, and a series of financial crises. Pollution, though now perhaps more widespread, is not nearly so intense as at the beginning of this period. Mr. Pentelow considered that an important factor leading to further improvement has 